\title{
Rachel Murphy (ed.), Labour Migration and Social Development in Contemporary China
}

Hui Xu

\section{OpenEdition}

1 Journals

Édition électronique

URL : http://journals.openedition.org/chinaperspectives/5285

DOI : 10.4000/chinaperspectives.5285

ISSN : 1996-4617

Éditeur

Centre d'étude français sur la Chine contemporaine

Édition imprimée

Date de publication : 1 juin 2010

ISSN : 2070-3449

Référence électronique

Hui Xu, « Rachel Murphy (ed.), Labour Migration and Social Development in Contemporary China », China Perspectives [En ligne], 2010/2 | 2010, mis en ligne le 05 août 2010, consulté le 21 septembre 2020. URL : http://journals.openedition.org/chinaperspectives/5285 ; DOI : https://doi.org/10.4000/ chinaperspectives. 5285

Ce document a été généré automatiquement le 21 septembre 2020.

(C) All rights reserved 


\section{Rachel Murphy (ed.), Labour Migration and Social Development in Contemporary China}

Hui Xu

1 Rachel Murphy (ed.), Labour Migration and Social Development in Contemporary China, London, Routledge, 2009, 204 pp.

2 EntitledLabour Migration and Social Development in Contemporary China, this book edited by Rachel Murphy addresses the relatively neglected but important issue of the interaction between internal migration and various dimensions of social development in contemporary China. Social development and economic development are two sides of the same coin (p. 1). In the past few years, while China has experienced rapid economic development due in large part to migrants, little attention has been paid to social development. The book is thus a timely and valuable response to this neglected component of China's development.

3 The book opens with a prologue by Dr. Frank Laczko, head researcher of the International Organization for Migration (IOM), and is followed with an introduction by Rachel Murphy, who presents us with the quintessence of this collection. Precise questions are considered thoroughly in each chapter, and cover a broad range of discussion, including the alleviation of poverty, remittance and inequality, Household Registration System (hukou) reform, social security, education, health, housing, labour rights, and civil society development. Given the vast number of people involved in migration in China, the book is highly policy oriented, encouraging new policy directions as well as policy development and reflection (p. 3). The editor has arranged the articles in such a way that each links logically to others; 
thus, the following brief review follows the original order of articles in the collection.

4 In the first article, using a macro approach and sophisticated analysis of national level statistical data, Dewen Wang and Fang Cai discuss the role of migration in rural income growth and poverty alleviation, greatly emphasising the positive impact of migration on China's poverty alleviation achievements. At the same time, they also point out the vulnerabilities of migrants facing "labour market discrimination and social exclusion" (p. 43), and call for policy reform to remove various institutionalised constraints. This would include abolishing the remnants of the hukou system (p. 44) and establishing a transferable social security system for rural migrants. Although focusing primarily on economic aspects, the article serves a special function in providing important economic background knowledge, which is indeed closely linked with social development, and thus necessary for the whole volume.

5 As mentioned by Dewen Wang and Fang Cai, one important channel for improving rural quality of life is the diversified income source from migrants' remittances. While confirming the positive economic effect of remittances, Rachel Murphy highlights some largely overlooked aspects, namely the immense human cost, both for migrants and their families (p. 48, p. 60), and intra-household inequalities (p. 61). A common human cost imposed on migrants is the welfare they sacrifice in order to remit their savings to family members. Intra-household inequality is a fairly new perspective in examining the effects of remittances in Chinese case studies. Three dimensions are considered by Rachel Murphy: inequality between migrants and the "left-behind," intergenerational inequalities, and inequalities along gender lines ( $p$. 61). For instance, Murphy argues that "information asymmetry" exists between migrants and the left-behind, thus the volume of remittance can raise a problem of inequality. To gain a more complete picture of this dimension of inequality, Murphy might add a complementary discussion from an inverse perspective: the phenomenon of the "left behind" can also be viewed as a "moral hazard," i.e., depending totally on remittances without taking serious responsibility for local activities. It is worth mentioning that the article is a rich and comprehensive literature review in the sense that the reasoning draws on influential theoretical and empirical research covering a broad range of social sciences in the study of remittances.

6 While remittance is the natural result of migration, the hukou system, a much debated subject that institutionally characterises and influences Chinese internal migration, is discussed in depth by Ran Tao. Through exploration of its historical roots, Ran Tao stresses the need to reform the hukou system, which is viewedas an institutional constraint closely related to the lack of welfare and social assistance in the areas of housing security programs and public school services for migrants ( $p$. 77). Whether or not hukou is responsible for the different allocation of 
social insurance, and if so, to what extent, is not evident or easily identifiable. In this article, however, the author suggests, rather innovatively, that the current inadequacy and ineffectiveness of the social insurance allocation system now seem more related to the nature of employment (p. 77) than to the hukou system. Specifying the responsibilities of the hukou system is an excellent idea in this article. However, to support this idea, it would be more convincing if the author could have further explained the reasons behind this assertion, providing additional comparative discussion on the differences or similarities in social insurance coverage between migrants and native workers under the same employment regime.

7A distinctive social consequence generated by the large-scale migration phenomenon is the emergence of migrant-run schools in many urban areas in China. Drawing from participant-observation ethnological field work in "Bright day school" in Beijing, T.E. Woronov's article provides an excellent case study for exploring the specific features of migrant-run schools: reasons for their establishment, facilities, teachers, classes, schedules, students, curriculum and lesson content, and mobility. The paper takes an interesting approach by comparing the education provided in migrant-run schools with that of public schools in Beijing, effectively clarifying the current advantages and disadvantages of the educational situation in migrant-run schools. The educational advantages of migrant-run schools, as opposed to village schools, are commonly recognised for their beneficiaries: migrants, their children, and teachers. However, a constraint in these advantages becomes evident due to the education structural barrier ( $p$. 108) ${ }^{1}$ that restrains the further education of migrants' children in the city. Another obvious obstacle that reinforces the constraints of educational integration of migrants' children in the city is the strong prejudice of urbanites, which the author discusses explicitly to evidence its psychological implications (p. 109). Here, the author focuses in particular on the prejudices prevalent among urban residents towards migrants and their children, and on the discussion among scholars about this prejudice. However, one might also expect to see discussion of the psychological implications for migrant children facing these unfavourable attitudes, particularly those enrolled in the same public schools as local urban students.

${ }_{8}$ Caroline Hoy, in the next article, explores an almost forgotten issue in migration study: the reproductive and sexual needs of migrants. While these two problems are a matter of concern for the population as a whole, they are much more serious among migrants due to the dominant social stereotype of them as economic labourers rather than full human beings, which complicates many aspects of their lives, sexuality included (p. 115). Moreover, in government service provisions, the focus on married women remains deeply entrenched (p. 121), with ongoing attention and focus on fertility regulation rather than on the protection of sexual health and sexual life. Insufficient education on the subject also matters. Thus, the author successfully draws attention to 
insufficient social and political awareness, and the lack of service provisions to meet the reproductive and sexual health needs of migrants. Sexual and reproductive health education for migrants is one of the article's key points of discussion, in which the author tries to distinguish the particularity of (women) migrants from the general population. However, due to the paucity of information and research in this area on both the general and migrant population, the distinction between the two is not evident, and the article's discussion is mainly centred on the general population. The work thus calls for further social attention and academic research on sexual and reproductive education issues among the migrant population.

9 Poor housing is a common aspect of the migrant urban living experience. The types of unfavourable housing conditions currently encountered by migrants working and living in urban areas, and to what extent local governments contribute to changing these conditions, are thoroughly discussed by Yuping Wang and Yanglin Wang. Both provide rich evidence covering the experience of many cities, focusing particularly on their survey results in Chongqing, Shenyang, and Shenzhen. Through the presentation of empirical evidence of diverse aspects of housing conditions in each city, along with comparative discussions as the main approach, the paper concludes that poor housing is a common aspect of most migrants' urban living experience (p. 151). The latter part of the essay distinctively points out the causes of the ineffectiveness of the existing system, and thus has useful policy implications. The significance of the comparison and the effectiveness of the discussion might be enhanced if the authors could provide more background information concerning their reasons for choosing these particular cities for study, as well as basic background information on economic and geographical factors that might have a bearing on migrant living conditions.

10 Among the typical residential venue for migrants discussed by Yuping Wang and Yanglin Wang are dormitories provided by factories (p. 141), which are especially popular among women migrants working in line production. Pun Ngai calls this particular migrant living system a "dormitory labour" regime (p. 157). According to the author, the emergence of the "dormitory labour" regime is the result of the shift in responsibility from the state to the private sector, which indicates a serious deprivation of migrant workers' labour rights in the absence of effective protection from the government. Meanwhile, and in response to the dominant conditions of poor employment and the infringement of labour rights, collective labour associations for protecting labour rights have been developing outside the conventional trade union organisation. The article focuses in detail on one very important experience of a dynamic NGO in Southern China, the Chinese Working Women Network (CWWN), which fights for the rights of women migrant workers. The phenomenon of the "dormitory labour" regime characterised by "living-at-work" (p. 158) is a very popular arrangement among migrants, but we lack a proper understanding of it. 
Pun Ngai's discussion serves to draw our attention to this phenomenon, and calls for further research on areas such as its psychological impacts on female migrants, and on their social participation, peer relations, and economic productivity.

11 In addition to CWWN, other social organisations organised either on behalf of migrants or by migrants themselves have generated more activities addressing social concerns for migrant workers' needs in recent years. Jude Howell discusses this question in depth in the final chapter, in which he describes and analyses the organising experience on behalf of migrants and by migrants themselves, based on rich documentation. The achievements of civil society can be represented by the development of organisations working on behalf of migrants; meanwhile some concerns accompany this growing phenomenon, primarily in terms of the application of the empowerment agenda, a lack of unified strategies, and the problem of sustainability due to financial dependence on external donors. Nevertheless, the services provided by organisations working on behalf of migrant workers are valuable (p. 189) in addressing various specific projects for migrants' needs, such as legal rights, social justice, gender equity, and health. Compared with organisations that organise on behalf of migrants, the organising achievements of migrants themselves have much less impact, since all such attempts have been short-lived (p. 186), primarily due to certain government restrictions (p. 189). This final article serves as a general summary of achievements and the gap that remains in social developments relating to migrants, reflecting the main theme of the book as a guideline to inspire reflection and encourage further attention to and efforts on behalf of migrants.

\section{NOTES}

1. Since many migrant schools are not registered with the local authorities (jiaowei), graduating students obtain no certificate of their studies. The children either have to be sent back to their home villages to continue their study or choose to stay in the city with their families, but begin to work early. 